\title{
The Role of Media in Peaceful Resolution of Civil Wars: The Case of Tajikistan from the Point of Peace Communication
}

\author{
Behruz Raisov \\ Anadolu University, Turkey \\ Ali Simsek \\ Anadolu University, Turkey \\ E: asimsek@anadolu.edu.tr
}

Article Info:

Received 14 March 2018

Accepted 18 June 2018

Published 16 July 2018

DOI: https://doi.org/10.12973/ojcmt/2652

The role of the media in conflicts has recently gained importance due to the fact that civil wars have taken place in various parts of the world. This role can either be positive or negative. Therefore, it is important to investigate how media outlets have been used during conflict situations in countries where civil wars have occurred. In light of the background information regarding Northern Ireland, Bosnia-Herzegovina, Indonesia, Sri Lanka, Ruanda and Sierra Leone, the case of Tajikistan civil war was explored in this study from a peace communication perspective. Content analysis, interviews and document analysis techniques were used to collect data. In particular, newspaper coverage, brochures, and radio broadcasts during the civil war were analyzed. The results show that the Tajikistan civil war started in the context of weak socio-political climate, visible influence of foreign countries, and a loss of long-exercised control over media through the state apparatus. Before the war media caused increasing tension in the society but the role of media has changed during the peace talks. Significant work has been done to end the civil war in Tajikistan in terms of all aspects of peace communication. The media generally played a vital role in promoting peace among people and encouraging the fighting parties to reach a consensus. In general, both the pro-government and pro-opposition media acted toward the direction of making peace. In particular, the progovernment newspapers Jumhuriyat and Sadoi Mardum reflected a peaceful view on behalf of the official government. The radio program Khoki Vatan (Homeland), which was created and broadcasted by the Radio of Tajikistan, also played a major role in promoting peace.

Keywords: peace communication, civil war, media, peace, conflict resolution

\section{INTRODUCTION}

The media has influenced the field of communication more than any other factor throughout the history. We have particularly witnessed the great impact of mass media both in 
societal and personal contexts. Therefore, when somebody talks about communication, people usually think of media. Although most of the communication activities are realized through media, communication does not mean only media. Every act and tool that provides opportunities for a dialogical discourse plays a mediating role in communication. None of the sub-areas of communication is exempt from this reality.

Peace communication is a sub-field of communication. It aims to promote and bring about peace among the parties attending the communication process. Any method and technology that are usable for communication can be employed in peace communication. Because peace communication usually deals with conflict situations, campaigns of peace communication are often multifaceted.

It is well-known that the media has been used for political and diplomatic purposes for decades. Humanity has witnessed this reality in the case of the Cold War between the United States and the Soviet Union. After this ideological conflict has ended, the world media has been used widely in the new political arena.

Media has been extensively used during the wars and conflicts. For this reason, at a time when wars have taken place in various parts of the world, the role of media has increased. Therefore, it is important to know how media were used in the past conflicts and learn from the previous mistakes to develop healthy approaches to current conflicts.

Investigations of relationship between media and civil wars in some countries showed that the role of media can be either positive or negative. Especially in emerging and realization of the genocide in Rwanda, the Radio Rwanda and Radio-Television Libre des Mille Collines (RTLMC or RTLM) were used for negative purposes (Hoffman, 2013:4). These radios were progovernment, therefore the government used them as a tool for propagating hatred against Tutsis. During the genocide, RTLM called youth to "work" (this radio used the word "work" to kill Tutsis). For example RTLM broadcasted the programs with this sentence: "Guys work, work everywhere, come work with army. For defending our country come work with government" (RTLM, 5 April 1994). Similarly, RTLM called people with this sentence: "Hello guys, did you start your work (killing Tutsis)?" (Li, 2007, p.96). According to the language expert Matthias Ruzindana, between 1990 and 1994 Kangura newspaper used and encouraged the widespread uses of the following meanings in Rwandan society as: to massacre, to exterminate, to eat up, to clean, the work, the working, the workers, communal worker, municipal worker (Kimani, 2007, p.110). Commonly Kangura called Tutsis with icons. The icon which was used most often is "inyezi - cockroaches" (Kabanda, 2007, p.68). Probably the strangest publication that Kangura published was "Hutu Ten Commandments". This publication showing clearly that the hatred of Hutu against Tutsi was in very high level. Therefore, it is clear that the role of media in Rwanda conflict was negative(Batware, 2012).

On the war in Bosnia and Herzegovina, the role of the media has been negative too. The 1992's war in Bosnia and Herzegovina consisted of three sides: the Bosnians (Muslims), the Croats and the Serbs. Since these three sides are separate ethnic groups, the media have always acted in the national/ethnic interests of these groups and portrayed an image of "they" and "us".

On the other hand, in the case of the Northern Ireland, the media, especially the press, played a positive role (Archick, 2015). According to Wolfsfed (2004, p.174), although the role of the media in the Northern Ireland conflict was not ideal, it has been positive and very important. According to Seán Farren, a member of the Social Democratic and Labor Party (Nationalists), Church and the media have opposed to violence. Seán Farren said, "The national media has helped us, it showed the activities which we did on behalf of peace" (Baghdasaryan, 2014). There were newspapers which supported conflicting sides and the newspapers that didn't support any side. For example Irish News was a Nationalist newspaper, Newsletter and Belfast Telegraph were Unionist newspapers (Wolfsfed, 2004:174). Press on both sides acted positively about Good Friday Agreement. For example, Irish News (Nationalist) published these headings: "Today is 
only the beginning, it is not the end (p.1)"; Irish Times: "Parties unite in welcome for pact" (p.4); "Prayers are answered" (p.4); "The long wait, the long Good Friday" (p.5) etc. The Belfast Telegraph (Unionist) also emphasized the positive aspects of the agreement: "Destiny Day" (p.1); the front page... moving picture of two women - one Protestant and one Catholic - praying at their respective churches. The caption read: "United in prayer for peace" (Wolfsfeld, 2004, p.168).

The present study is a case study that examined Tajikistan civil war in respect to what was experienced in 1992-1997. The civil war in Tajikistan is unique in many respects. Unlike many civil wars that happened before, this war wasn't a war between various ethnic or religious groups. It was a war between peoples who had different political opinions about building the new Tajikistan after independence. There have been some political investigations on this subject but there has been limited research in terms of the media influence during the civil war. For this reason, the civil war in Tajikistan and the role of media in this war have been chosen as a topic for the present study. The study examined the media environment between 1994 and 1997. Although the conflict emerged in 1992, peace talks began in 1994 and ended in 1997 with the signing of the National Peace Agreement (NPA). In this study, it was investigated how the conflict occurred, which parties participated in the conflict, what the demands were, how the parties behaved, the media environment at that time, how the media used by conflicting sides to reach peace. Results of the present study will be useful in shedding light on issues of conflicts and role of the media in civil wars.

\section{The History of Civil War in Tajikistan}

Tajikistan, like other Central Asian countries, was a part of the Soviet Union until 1991. When the Soviet Union disintegrated, Tajikistan became an independent country on September 9, 1991. However, Tajikistan wasn't politically, economically and socially ready for independence because Tajik politicians were accustomed to be regulated from Moscow during the Soviet period. When the country became independent, Tajik politicians couldn't organize a politically strong government. Besides, the economy of the country was destroyed. Therefore, after independence, political conflicts started in Tajikistan. Then, in 1992 political conflicts turned into a civil war and continued until 1997 (Schmitz, 2015).

According to Faroughi (2002, p.39) the basic reasons of Tajikistan civil war were set in 1980s. One of the influential factors for beginning of the civil war, was Mikhail Gorbochov's "glasnost" and "perestroika" policies. As a consequence of these relatively west-oriented policies, different democratic movements and organizations appeared in most Soviet Union countries. Tajikistan was not an exception in this case. There appeared different political parties, religious movements and social organizations. For example, at the end of 1992, there were 18 political parties, 16 social-political organizations, 14 associations, 9 nationally known communities and 8 religiously organized groups in Tajikistan (Panfilov, 2003, p.19). Of these, the most influential opposition organizations were:

- Islamic Revival Party of Tajikistan (IRPT)

- Rastokhez (cultural and national movement)

- Democratic Party

- La'li Badakhshon

The first presidential elections in Tajikistan was conducted on November 30, 1990 and Khahor Mahkamov (communist) won. When a coup against Gorbachev took place in Moscow in August 1991, the political tension in Tajikistan increased too. At the end of September 1991, due to pressure by democratic opposition, President Mahkamov resigned (Panfilov, 2003, p.10). The second presidential elections in which communists and opposition democrats participated, was held in Tajikistan in November 1991. Communist Rahmon Nabiyev won the second election as well. The candidate of all the opposition groups, Davlat Khudonazarov, was defeated but the opposition groups didn't accept the results of elections (Buşkov \& Mikulskiy, 1996). 
After coming to power, Rahmon Nabiev's government started to apply pressure on opposition parties. On March 6, 1992 a democrat politician Maksud Ikromov and on March 11, 1992 the chairman of Rastokhez movement Mirbobo Mirahimov were taken to prison (Buşkov \& Mikulskiy, 1996). That is why protests intensified in March 1992 (see Figure 1).

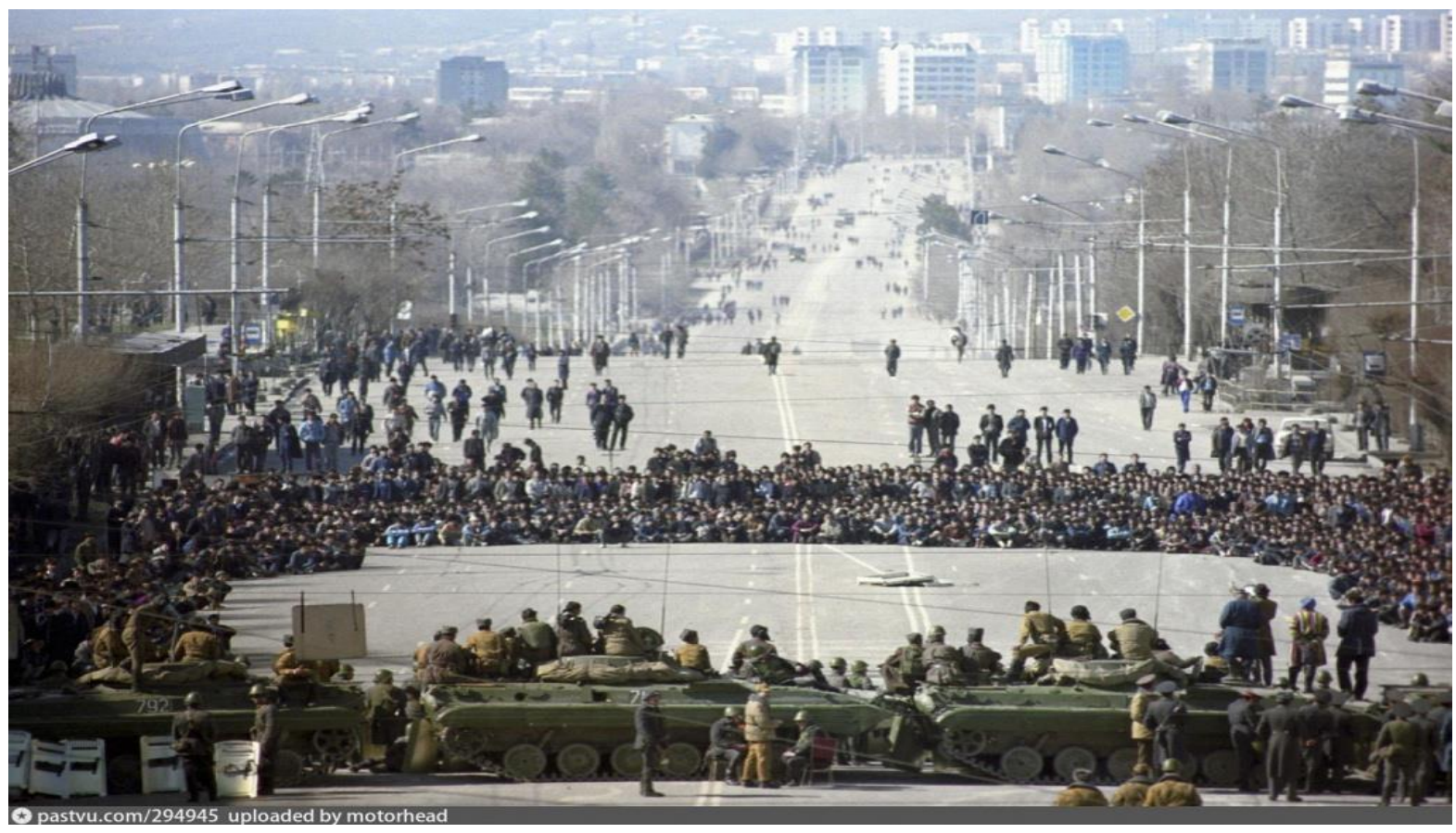

Figure 1. Opposition Come Together for Protests (https://sputnikipogrom.com/ war/49350/theunfamous-war-1/\#.WWOpHYTyjDc E.Norin)

As a result of the protests, a coalition government that consisted of communists and opposition parties was formed in May 1992 but the opposition continued to pressure on the communist side and the second president of Tajikistan Rahmon Nabiev resigned in September 1992 (Panfilov, 2003, p.10). The $16^{\text {th }}$ Grand Assembly in which most conflicting groups participated was held in Khujand (city in North of Tajikistan) on November 16, 1992. At this meeting the resignation of Rahmon Nabiev was accepted and the presidential system was simplified. After this, Emomali Rahmonov (supported by the communists and the National Front) was chosen as the Parliament Speaker and Abdumalik Abdullojonov was chosen as the Prime Minister. At that time the Parliament Speaker had more influence. Beside these changes, a ceasefire protocol was signed by the conflicting sides (Bobokhonov, 2011, p.78). However, the conflicts didn't end and the pressure on opposition parties continued. Because of this situation, the opposition groups moved to Eastern regions of Tajikistan and Tajikistan-Afghanistan border. In Afghanistan all opposition groups came together and formed the Union of Tajik Opposition, in which Said Abdulloh Nuri (the head of IRPT) was chosen as the chairman. People who supported the opposition parties also moved with opposition political groups (see Figure 2). 


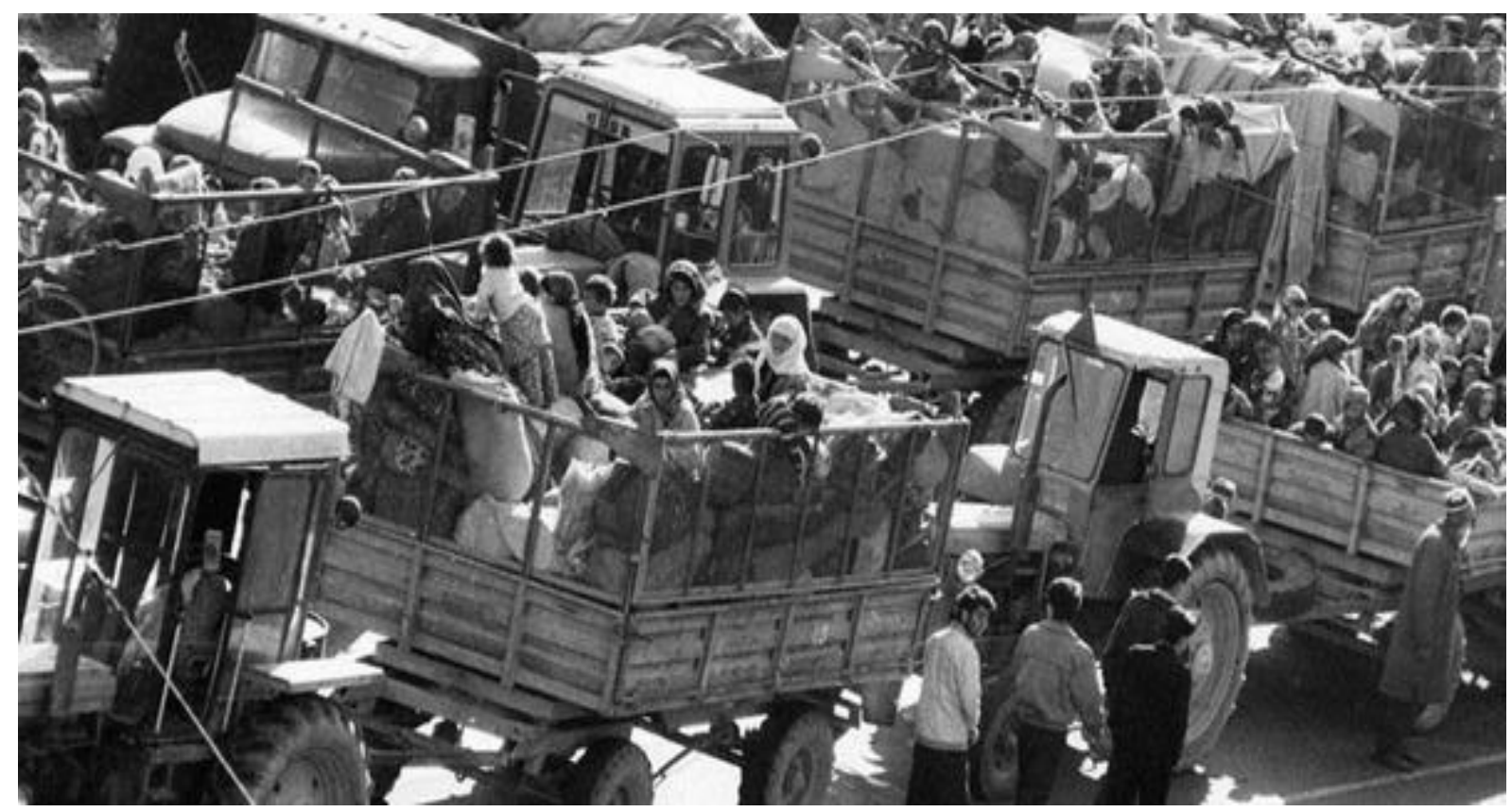

Figure 2. The Moment People Leave War Zones (https://sputnikipogrom.com/war/ 49350/theunfamous-war-1/\#.WWOpHYTyjDc E.Norin)

Approximately 60 thousand people were killed in the first year of civil war. In the whole period of the conflict about 150 thousand people lost their lives. According to United Nations (UN) publications, 600 thousand people became refugee inside the country and 80 thousand became refugee abroad (mostly in Afghanistan) (Bobokhonov, 2011, p.81; Panfilov, 2003, p.5). Thus, the conflict has continued from 1992 until signing the National Peace Agreement (NPA) on June 27, 1997.

\section{Major Reasons of Civil War}

Like many other civil wars that happened around the world, there are certain causes for the civil war in Tajikistan. There are some general factors that were emphasized by researchers. The following is a short summary of these reasons:

Political and economic weakness - When the Soviet Union collapsed, the Tajikistan government was very weak. As the Dartmouth Conference participants from Tajikistan said in March 1993 "independence came to us suddenly, we were not ready for it (Saunders, 2001)". Economic situation was difficult too. None of the institutions worked properly. For example, Tajikistan used "ruble" (Russian currency) until 1995. There was not a national currency. That is why, Tajikistan was depended on Russia economically.

The difference of political views - As it was mentioned before, Mikhail Gorbochov's "glasnost" and "perestroika" policies during 1980s influenced the political situation in member states within the Soviet Union. Different political and social groups with different views emerged in Tajikistan. Most of the movements were based on religious values, national interests and democratic views which didn't match the communist view of the government of Tajikistan (Buşkov \& Mikulskiy, 1996). In addition, opposition groups didn't want presidential system, they tried to build a parliamentary system. 
Regionalism - The issue of regionalism played a very negative role in the Tajikistan civil war. In general, during the war regionalism looked like this: regional electorate supported politicians who came from their own regions.

The influence of foreign countries - In the beginning of the 1990s conflict in Tajikistan was political only but when foreign countries started to follow their interests, political conflict changed to military civil war. Russia and Central Asian countries supported the National Front which fought for official government (Bobokhonov, 2011, p.76). Iran and Afghanistan supported religiously-oriented UTO because of their national interests and Islamic views (BBC, 2013). Russia and Central Asian countries opposed to UTO because its purposes didn't served their interests and they were afraid about spreading of Islamic views in the region.

\section{Phases of Reaching Peace in Tajikistan}

The Peace Agreement, which was signed in Tajikistan was an exceptional event. According to UN information, this agreement was one of the successful results in the world. The UN played an important role in reaching peace in Tajikistan. On March 2, 1992 Tajikistan became a member of the UN. After becoming a member of the UN, the Tajikistan government asked the UN to intervene in the conflict there. On January 21, 1993 the UN initiated a mission and on May 16, 1993 the UN Secretary General's representative Ismat Kittani came to Dushanbe. Kattani met with heads of Uzbekistan, Russia, Kyrgyzstan, Iran, Pakistan and Saudi Arabia. Then he met with various key persons from the opposition side. Thus, with the significant influence of the UN, an healthy environment for peace talks between Tajiks emerged in April 1994 (Abdulloev, 2013, p.104).

Peace talks officially started in April 1994. Generally, negotiations were carried out in three steps (Panfilov, 2003, p.307):

- Official negotiations in which documents were signed;

- Consultative talks in which problems were discussed;

- High level talks in which President Emomali Rahmonov and the leader of UTO Said Abdulloh Nuri were participated.

The issues which were not resolved in other meetings were discussed in these meeting. All peace talks were conducted in the countries which the two sides of the conflict agreed upon. Official negotiations were realized in nine rounds.

\section{Round 1}

The first peace talk was carried out on April 5-19, 1994 in Moscow, with the participation of the UN, Afghanistan, Russia, Iran, Pakistan, Kazakhstan, Kyrgyzstan and Uzbekistan. This meeting did not produce viable results but the first step was taken. Conflicting sides agreed to sit around the negotiation table.

\section{Round 2}

The second round of negotiations took place on June 18, 1994 in Tehran. The crucial issue in this meeting was the "ceasefire and other hostile movements" were discussed. Parties have shared their ideas on the subject but they didn't seem to understand each other.

\section{Consultative talks}

After the second round of negotiations on September 12-17, 1994 in Tehran consultative talks took place. During these talks "interim ceasefire in the Afghanistan-Tajikistan border and 
in the territory of Tajikistan" was agreed and forming of a Common Ceasefire Commission was discussed (Sarafieva, 2013, p.85). The representatives from the two conflicting sides participated in this commission.

\section{Round 3}

Third meeting took place between October 20 and November 1, 1994 in Islamabad. Both sides blamed each others for not respecting and implementing points which were agreed on before. In particular, the opposition emphasized that the Russian side supporting the official government in talks had a negative impact on the negotiations process. Despite the disputing views, a "Protocol about Forming the Common Ceasefire Commission" was signed in this round.

\section{Consultative Talks}

This meeting took place on November 19-26, 1995 in Moscow. The important thing which was agreed in this meeting was that a high level meeting in Kabul was agreed. In addition, the date of the fourth meeting in Almaty was agreed as May 22, 1995.

\section{High Level Meetings}

First high level meeting took place in Kabul on May 17-19, 1995. This meeting was between the Tajikistan's President Emomali Rahmonov and the UTO's leader Said Abdulloh Nuri. During the talks, the ceasefire agreement was extended until August 26, 1995. This level of dialogue has created a positive perception on the situation (see Figure 3).

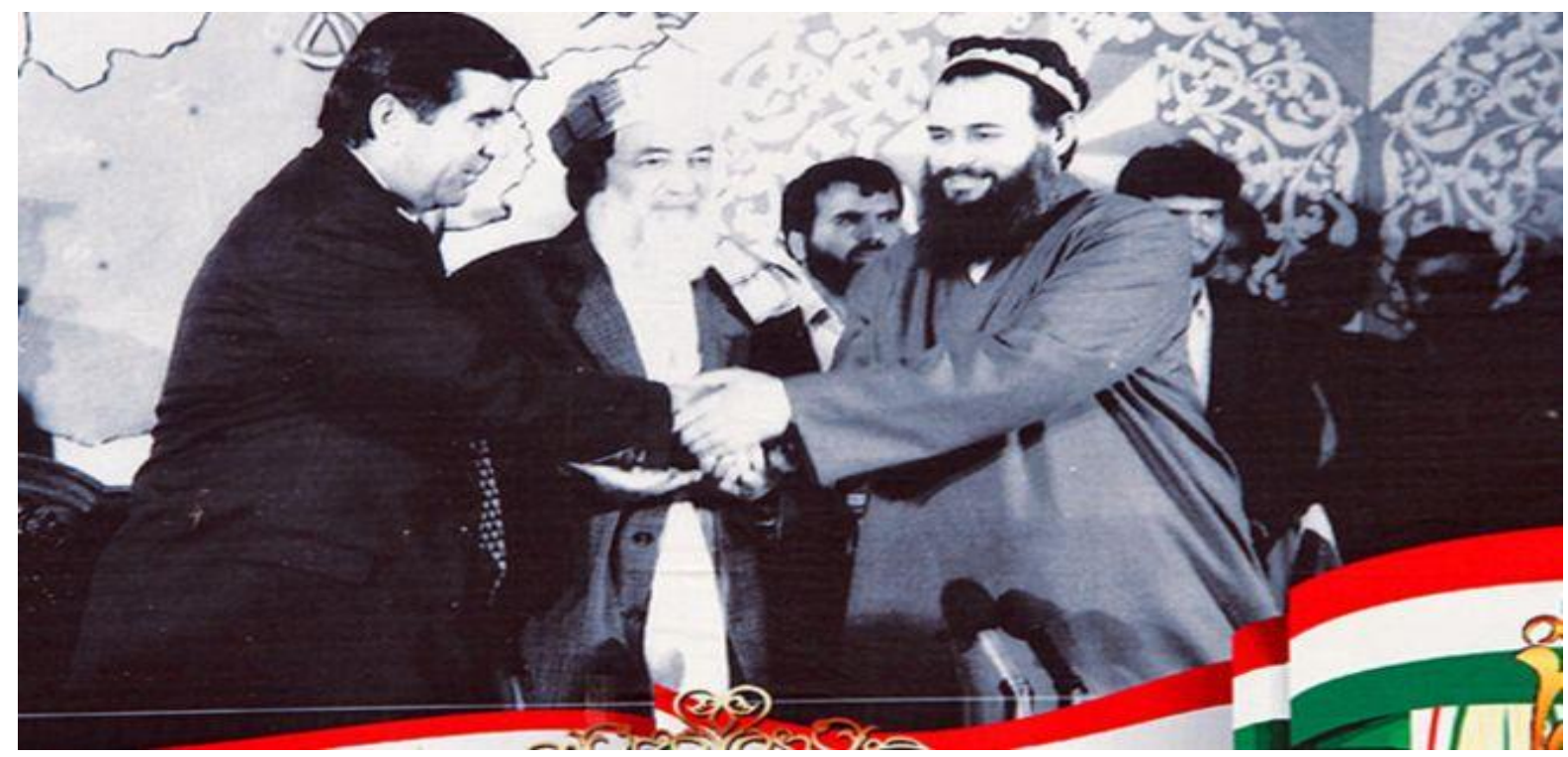

Figure 3. On the Left E. Rahmonov, in Middle Afghanistan's President B. Rabbani and on the Left UTO’s Leader S.A. Nuri (ruzgor.tj).

\section{Round 4}

The fourth round of the talks was carried out in Almaty (Kazakhstan) between May 22 and June 2, 1995. In this meeting the constitutional issues and the future political system in Tajikistan was discussed. The opposition proposed to establish a temporary government but the 
government delegation did not accept this idea. However, the government delegation stated that they were ready to see opposition representatives in the government.

\section{High Level Meetings}

The second high level meeting took place in Tehran on August 17, 1995 with the mediation of Iran. Both sides decided to take concrete steps to implement the agreements. In addition, they discussed the basic principles of NPA. They extended ceasefire situation until September 18, 1995.

\section{Round 5}

This round took place on November 30, 1995 in Ashgabat (Turkmenistan) in three stages: the first stage was realized between November 30 and December 22, 1995; the second stage between January 26 and February 26, 1996; the third stage on July 8-21, 1996. The reason that this round took place in three stages were the increased level of conflicts and not realizing the agreements which were signed before.

\section{High Level Meetings}

On December 10-11, 1996, E. Rahmonov and S. A. Nuri met in the Khost region of Afghanistan. After this meeting the "Protocol about Regulation of the Military-political Situation" was signed. Khost meeting was very successful (see Figure 4). In addition, the issue of forming the National Peace Commissions (NPC) which would control the implementation of peace agreement was discussed (Panfilov, 2003, p.318).

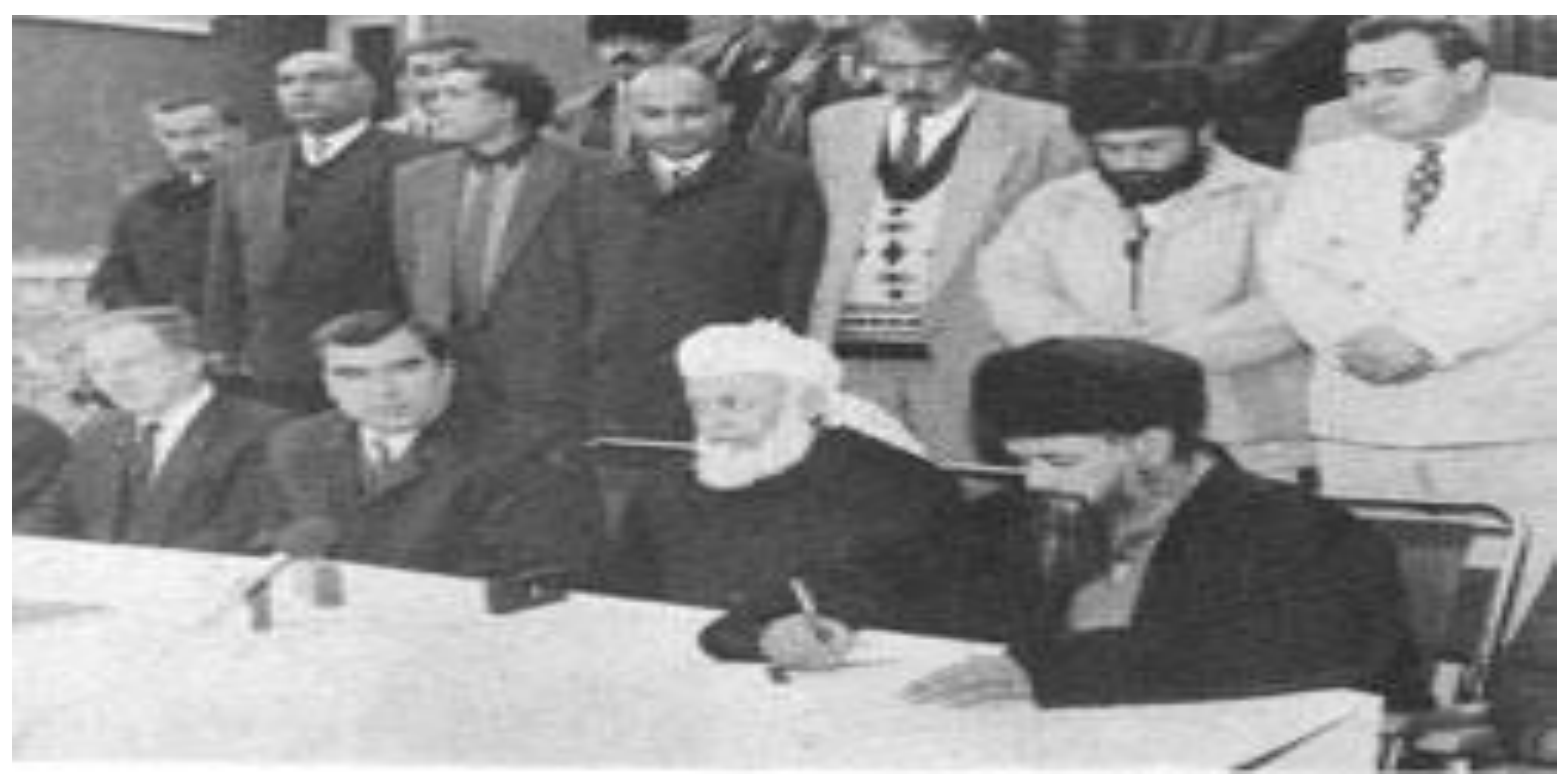

Figure 4. Khost meeting, in the right UN representative Gerd Merrem, Tajikistan's president E. Rahmonov, Afghanistan president B. Rabboni and UTO's leader S.A. Nuri (ruzgor.tj).

\section{High Level Meeting}

After the Afghanistan summit, high level leaders met again on December 23, 1996 in Moscow. In this meeting details of National Peace Commission (NPC) were discussed. Both sides agreed that the Head of the Commission would be selected from the opposition side. In addition, 
the responsibilities of the Commission was decided. One of the commission's responsibilities was controlling of returning of refugees. They were agreed during political tasks that the commission should work with the President.

\section{Round 6}

This round took place on January 5-19, 1997 in Tehran. Three general topics were decided: the sides agreed about forgiving each other and accepting general amnesty law; the central election commission entitled to make temporary elections and to define quotas for UTO's representatives in elections; reformation of the government and giving quotas to UTO's representatives for joining the government institutions. In addition, the protocol about refugees was also signed (Panfilov, 2003, p.319). The government took the responsibility for refugees.

\section{High Level Meeting}

On February 20-21, 1997 the leaders of the conflicting sides met in Mashhad (Iran). They talked about the next activities of NPC. They decided that commission would consist of 26 people, with equal numbers of representatives from the both sides. The NPC consisted of four commissions with regard to political issues; issues related to refugees; military issues; issues related to laws.

\section{Round 7}

This meeting was held in Moscow between February 26 and March 6, 1997. At this meeting military problems and the issues related to adaptation of UTO forces to military structures of Tajikistan were emphasized. At the end of the meeting, the Protocol on Military Affairs was signed. According to this protocol, President of Tajikistan, the head of UTO and the UN representatives had to control the process of the disarmament and dissolution of the UTO and the reform of the military structure of the Republic of Tajikistan. Both conflicting sides were obliged to inform each other about their military forces.

\section{Round 8: First Stage}

The eighth round took place in two stages in Tehran: the first on April 9, 1997 and the second on May 22-28, 1997. The first stage was stopped due to UTO's objection. The appeal of the Tajik government, which requested to arrest 11 members of UTO in Russia and other regional countries caused the objection.

\section{High Level Meeting}

Because Round 8 wasn't successful, the high level meeting took place in Bishkek on May 16-18, 1997. Leaders signed the Protocol on Political Issues. The protocol consisted of four parts: adoption of the act on the mutual dissolution of the military groups by the President and the UTO's head; constitute a central electoral commission for an interim period to include $25 \%$ of representatives of UTO members; reforming of the government and the accepting UTO representatives there; dissolution of UTO military groups and their adaptation into the government's military forces. 


\section{Round 8: Second Stage}

The second stage of Round 8 took place in Tehran on May 22-28, 1997. The "Protocol on Guarantee of General National Peace Agreement in Tajikistan (NPA)" was signed. The guarantors of the agreement were UN special representative, the head of the OSCE in Tajikistan, representative of the Organization of the Islamic Conference and representatives of other guaranteed countries. Thus, this Protocol encompassed the basic principles for access to peace and has become one of the last documents of the peace talks among the Tajiks.

\section{Round 9}

The last peace talk among the Tajiks took place in Moscow on June 27, 1997. This meeting was held with the participation of President E. Rahmonov and the UTO leader S. A. Nuri and during this meeting decisive document "General Peace Agreement in Tajikistan (National Peace Agreement)" was signed (Sharafieva, 2013, p.89 (see Figure 5).

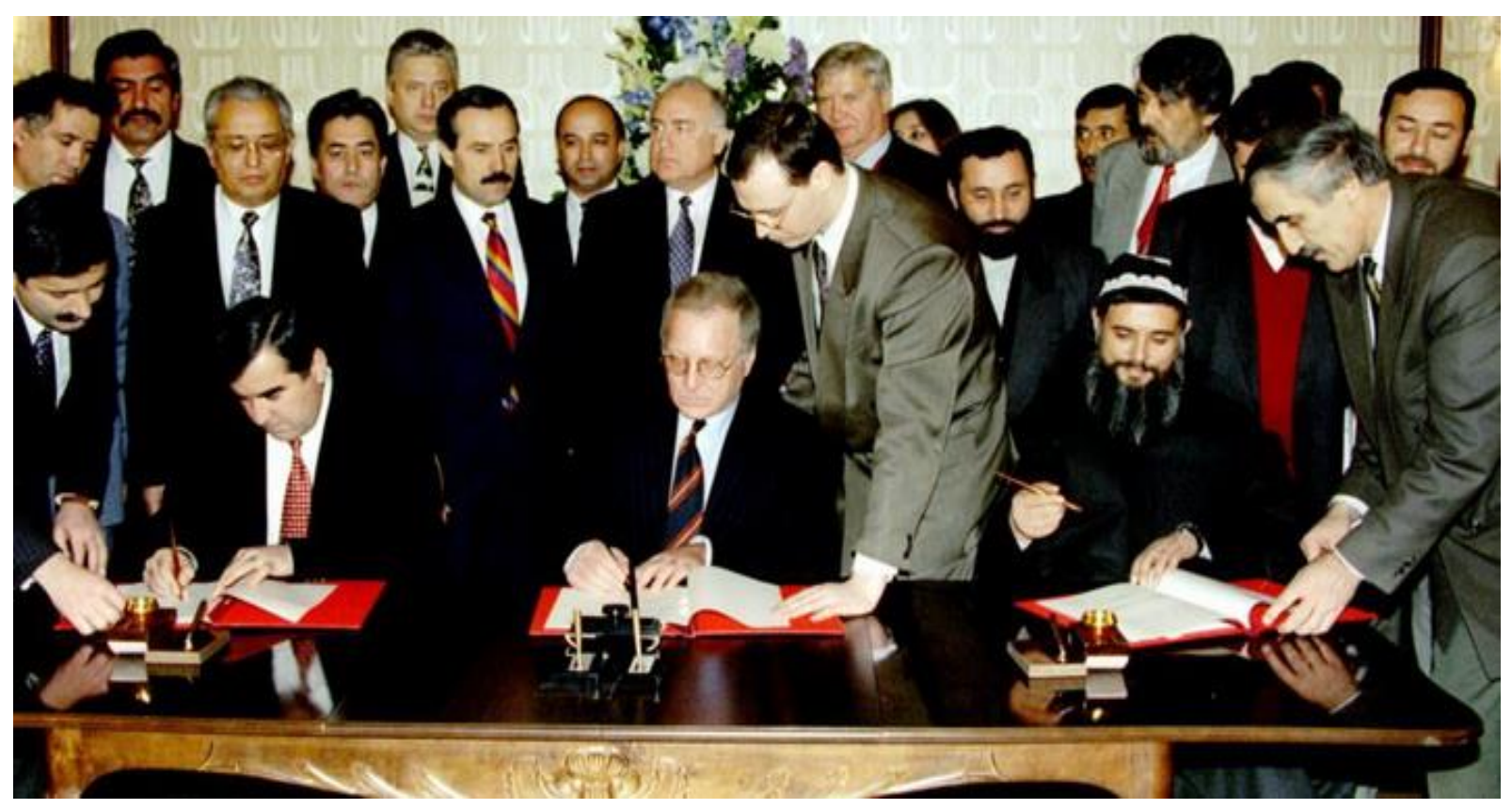

Figure 5. From the Left the President of Tajikistan E. Rahmonov, in the Middle UN Representative Gerd Merrem, in the Right the Leader of UTO S. A. Nuri Signing NPA.

\section{Communication Initiatives for Reaching Peace}

Of course, all the work that was done to reach peace in Tajikistan was important. However, there were a few initiatives that needed to be emphasized. These initiatives helped the conflicting sides listen and understand each other. After these initiatives, it was possible that conflicting sides tried to find solutions.

\section{Dartmouth Conference}

This conference has led the launch of peace negotiations during the Tajikistan conflict. The conference started in 1960 in the US. The aim of the conference was keeping relations between people of the United States and people of the Soviet Union. When the Soviet Union collapsed in 1991, the conference members made three decisions: 


\section{Focus on Russia-US new relations; \\ 2. To take experience in the scientific context of the dialogue processes in the 1980s; \\ 3. Experiment their experiences in a conflict that has arisen in the Soviet Union.}

Tajikistan was chosen for the third target. The reason for choosing this country was that it has an important geographical location in the region (Saunders, 2001). Conference conducted its meeting with participation of the Tajikistan authorities and key persons from conflicting sides (Murodov, 2015, p.83) but none of the participants represented their organizations. They took part in the conference as individuals. Participants at the first three meetings during March, May and August 1993 tried to find answers to such questions as: In your opinion what caused the emergence of the civil war in Tajikistan? What are the ways of stopping violence?

In the following periods, the conference participants searched how to initiate peace talks. For this purpose, they first learned how conflicting sides would react to the negotiations. One of the problems that appeared to the participants was that there were different groups of opposition. In order to initiate negotiations, it must be one opponent against the government. After the fourth meeting of the conference, the opposition leaders gathered in Tehran to form the UTO and drafted a document which showed their position about peace talks. At the fifth meeting of the conference in January 1994, the opposition participants expressed their views on peace talks. Government participants said they would talk to the government in this matter. Thus, a few weeks later, the government of Tajikistan, officially declared that it was ready to join peace talks under the auspices of the UN (Imomov, Saunders \& Cufrin, 2014; Saunders, 2001). Hence, peace talks started between the Tajikistan government and the UTO in which Dartmouth Conference played a critical role.

\section{Common Ceasefire Commission}

The third peace talks was held in Islamabad between October 20 and November 1, 1994 and during this meeting the conflicting sides decided to form a Common Ceasefire Commission. The commission consisted of the two sides' representatives who would control implementation of the Ceasefire Agreement which was signed on September 12-17, 1994 in Tehran (Sharafieva, 2013, p.85). The commission worked with the UN representatives and operated under its supervision. However, commission work was very challenging (Hamad, 2009).

\section{Peace Propagate Group}

At the end of the high level meeting which took place on December 10-11, 1996 in Khost, Afghanistan E. Rahmonov and S.A. Nuri had signed the Protocol on resolving the militarypolitical situation in the regions and stopping all war actions (Sharafieva, 2013, p.87). At that time the media didn't work well. Therefore, the sides formed a special group which would explain the protocol's aims to people living in different regions. There were representatives in this group from both sides. When representatives from the conflicting sides visited regions, people understood that it was the time to stop killing each other (Hamad, 2009). Hence, the movement of the two conflicting sides together has increased the people's beliefs about peace.

\section{National Peace Commission}

In a high level meeting that took place in Khost the fighting sides discussed about establishing the National Peace Commission but it was possible to form it only during high level meeting held on November 23 in Moscow. There, the leaders of the two sides agreed about forming the commission and its activities. The purposes of the commission would be controlling the implementation of all agreements which were signed during the peace talks (Panfilov, 2003, 
p.318). The head of the commission was chosen from the opposition side who was S. A. Nuri. The commission started its activities on July 7, 1997.

In general, the missions of the commission were divided into two parts (Hamad, 2012).

1. The missions that would be realized directly by the commission were:

- implementation of all agreements that were signed during peace talks;

- encouraging refugees return, assuring their safety, helping them enter into social life;

- proposing changes in laws about the political parties, movements and mass media.

2. Missions that would be realized by the commission and the President together were:

- presenting changes to the constitution and preparing it for elections;

- proposing a new law on parliamentary elections and generalizing it if necessary;

- constituting a Central Election Commission for the interim period;

- offering 30\% quota to UTO's representatives in government departments;

- ensuring that the opposition forces are united with the government army;

- controlling the exchange of all prisoners and releasing unjustified prisoners;

- drafting legislation on mutual forgiveness;

- changing the military and the political movements into legal parties;

- determining the election time for the new parliament under the auspices of the UN.

Commission had four sub-commissions (Nuri, 2010):

1. Political subcommittee - Head Prof. Dr. Ibrohim Usmonov (from the government);

2. Law subcommittee - Head journalist Otakhon Latifi (UTO);

3. Subcommittee on military affairs - Head Habib Sanginov (UTO);

4. Sub-commission on refugees - Head Sukurjon Zuhurov (from the government).

\section{The Media Situation during the Civil War Period and Its Role in Reaching Peace}

During the Soviet Union Tajik media was controlled by the central government and operated on interests of the Central Communist Party. At that time the media operated in Russian and Tajik languages. However, at the end of the 1980s and in the beginning of the 1990s, the media environment has changed. With the implementation of the "perestroika" and "glasnost" policy, the media began to change and the alternative media which didn't support communist system started to emerge. This happened in Tajikistan too but the difference of the Tajik media was that the media (mainly press) propagated more national, religious and democratic values. In addition, most newspapers were printed in Tajik language and sometimes in Persian letters. According to Mirzo Salimpur (journalist), media freedom began in 1990 with the publication of the "Rastohez" brochure. Oleg Panfilov classified the press in the period before the civil war (until 1992) into three groups:

Opposition press: "Najot” (IRPT), "Rastokhez" (Rastokhez), "Orion”, “Oinai Sikandar". These newspapers were politically affiliated press and they defended the interests of the political parties or movements.

Private press: "Charoghi Ruz", "Tajikpress", "Dom", "Police", "Oh ho ho", "Jomi Jam", "Shahodat", "Payomi Haq", "Dunyo", "Adolat". The majority of these newspapers were operated by individuals. However, these newspapers also supported some political sides. For example, "Charoghi Ruz" newspaper was formed by journalist Dodojon Atoulloev but in many cases it supported opposition's political views.

Free press: "Haftganj", "Navidi Bozargon / Komercheskiy Vestnik", "Shafkat", "Sukhan", "Minbari Islom", "Somon", "Payvand". Some of these newspapers also supported political parties. For example, "Shafqat" and "Minbari Islom" supported IRPT (Panfilov, 2003, p.16). 
According to G.H ${ }^{1}$. in the beginning of 1990s Tajikistan's press was very democratic and did its real work. He said at that time Tajikistan was a "democratic island" (Interview 4, G.H., 17.05.2017; Interview 5, I.J., 22.05.2017). C.D. also supported this view and named that period "golden period" for Tajikistan media (Interview 2, C.D., 20.04.2017).

However, by taking advantage of these freedoms, some members of the media followed interests of some groups and acted unethically. Those, who say that the media played a negative role in the beginning of the civil war in Tajikistan, emphasized that the media used freedom in wrong ways. According to E.F. (journalist) the "perestroika" policy gave to media members a lot of freedom. When the media people had so much freedom, they didn't know how to use it. Therefore, these freedoms have been used for a number of unethical purposes and for different groups' goals. In particular, newspapers established by political parties or movements operated in their political interests. As a result, the newspapers did not fulfill their basic duties, as giving right news, to work for all people's interests and to be objective (Interview 3, E.F., 15.05.2017). Mirzo Salimpur said that the press of the time became a tool for politics and played a negative role in starting civil war in Tajikistan (Panfilov, 2003, p.16).

\section{Media in the War Period}

In the civil war period Tajikistan's media were divided into two groups along the lines of the conflicting sides. In the beginning of the war some pro-government press supported opposition political views (Interview 2, C.D., 20.04.2017). According to A.B., in spring-autumn 1992 period when radio and television were in the control of the opposition groups, the media served their interests. On the other hand, in December 1992, when opposition groups moved to Eastern regions of Tajikistan and Afghanistan, all opposition media were banned and the media environment changed (Interview 1, A.B., 05.04.2017; Interview 2, C.D., 20.04.2017). Most of opposition media (press) continued their operations abroad. Starting with the year 1993, the media in Tajikistan was generally in the control of the government.

In early phases of the Tajikistan civil war, as it was the case in most civil wars, the conflicting sides used media against each other. For example, some regional press, which supported "National Front" used unethical words against the opposition groups; similarly the press that supported the opposition called "National Front" as a criminal group (Interview 2, C.D., 20.04.2017).

In addition, there were foreign radios operating in Tajikistan such as BBC, Radio Ozodi (RFE/RL) and Radio Khuroson, which were very active indeed. Generally, these media outlets supported the opposition side (Interview 1, A.B., 05.04.2017). According to E.F., foreign media, which operated actively during the civil war in Tajikistan, acted for the interests of their own countries. Especially Russian media were very effective and they had no problem in their activities because the government provided them opportunities. However, other foreign media did not equally enjoy such opportunities, and in many cases they couldn't provide information from first-hand sources (Interview 3, E.F., 15.05.2017). In general, during the civil war, Tajikistan's media did not have sufficient opportunities because of economic and political crises.

\footnotetext{
${ }^{1}$ Note: It was decided not to disclose the personality of the people interviewed in terms of security and special coding was used. Thus, the letters of the English alphabet were selected according to the order of the interviewees. For example, the name of the first person interviewed is A. B. and the name of the second person is C. D. For this reason, only the letters and the date of the interview were shown as the source.
} 


\section{Media's Role in Reaching Peace}

Unlike some countries that experienced a civil war, the media in Tajikistan has been on the side of peace particularly in later phases of the war when the issue of peace was on the agenda. Politicians, intellectuals and journalists also tried to spread the idea of peace inside and outside of Tajikistan. Even the media, which supported conflicting sides previously turned their focus on the peace issue. During the peace negotiations, the media published all processes of meetings. In general, especially after the dialogue has gained momentum, the media of the conflicting sides played an important role in reaching peace in Tajikistan.

In this study, the role of the media during the civil war in Tajikistan were analyzed based on pro-government newspapers only. These newspapers were "Jumhuriyat (Republic)" and "Sadoi Mardum (People's Voice)". The reason of choosing these newspapers was that in the period of peace negotiations from 1994 until 1997 "Jumhuriyat" and "Sadoi Mardum" were very active and effective. At first, the purpose of the study was to analyze press coverage from both conflicting sides but because there were not pro-opposition newspapers in the archives only the coverage of the two leading pro-government newspapers were analyzed.

\section{Analysis of Pro-government Press}

In the analysis process, attention was paid particularly to news and articles which were published in favor of peace or against peace. Analysis covered years of 1994-1997.

Table 1. Coverage of "Jumhuriyat" and "Sadoi Mardum" Newspapers According to Supporting and Opposing Views Regarding Peace

\begin{tabular}{lrrrrrrrr}
\hline Newspapers & \multicolumn{4}{c}{ For peace } & \multicolumn{5}{c}{ Against peace } \\
\cline { 2 - 10 } & 1994 & 1995 & 1996 & 1997 & 1994 & 1995 & 1996 & 1997 \\
\hline "Jumhuriyat" & 29 & - & 10 & 22 & - & - & 2 \\
\hline "Sadoi Mardum" & - & 13 & 13 & 15 & - & - & - \\
\hline
\end{tabular}

Table 1 shows that both newspapers published news and articles in favor of peace. They published 61 content elements in Jumhuriyat newspaper and 41 content pieces in Sadoi Mardum newspaper in favor of peace during the period of 1994-1997. Only 2 content elements in Jumhuriyat newspaper were published against peace. One of those publications was "Opposition want to form an Islamic state (Jumhuriyat, 17 August 1996, p.1)" in which President E. Rahmonov criticized opposition groups about their purposes to build an Islamic state. It appears that the newspaper used the exact words of the President.

It is a known fact that the most important news items appear in the first page of a newspaper. Keeping this inm mind, as an indication of the assigned importance, the coverage of the newspapers was analyzed in terms of pages on which news and articles appeared. Table 2 demonstrates that the majority of coverage was published in the first page of the newspapers. It means that these newspapers paid serious attention to peace issue.

The news and articles which were published in "Jumhuriyat" and "Sadoi Mardum" in the period of 1994-1997 were also categorized by theme. The findings are presented below. 
Table 2. Coverage of "Jumhuriyat" and "Sadoi Mardum" Newspapers According to Page Numbers of the Relevant Contents

\begin{tabular}{l|r|r|r|r|}
\hline \multirow{2}{*}{ Newspaper } & \multicolumn{4}{|c}{ Newspaper's pages } \\
\cline { 2 - 5 } & Page 1 & Page 2 & Page 3 & Page 4 \\
\hline "Jumhuriyat" & 38 & 12 & 8 & 5 \\
\hline "Sadoi Mardum" & 24 & 5 & 10 & 2 \\
\hline
\end{tabular}

\section{Refugees}

a) "Homeland is better than the throne of Solomon" ("Jumhuriyat" January 8, 1994, p.2). In general, this article was about "Khoki Vatan (Homeland)" radio program and its purposes. As an article informing the main purpose of the program was propagating peace and helping refugees to connect with Homeland and their families.

b) "Refugees, how are you? ("Jumhuriyat" January 19, 1994, p.2).

c) "The call of President E. Rahmonov to citizens who were abroad" ("Jumhuriyat" January 15, 1994, p.1. See Figure 6).

In this appeal the President E. Rahmanov called citizens with these words: "Dear citizens! Republic of Tajikistan - the Homeland of all of us is passing through a lot of political changes. We should discuss our Constitution and put it to the elections... There are peaceful environment and mutual forgiveness in our country. For several months our negotiations has been continuing with different opposition groups... Everybody in Tajikistan is waiting for you... Government is ready to help you return... Dear citizens, we say "You are welcome" to everybody who want to return to the Homeland..."

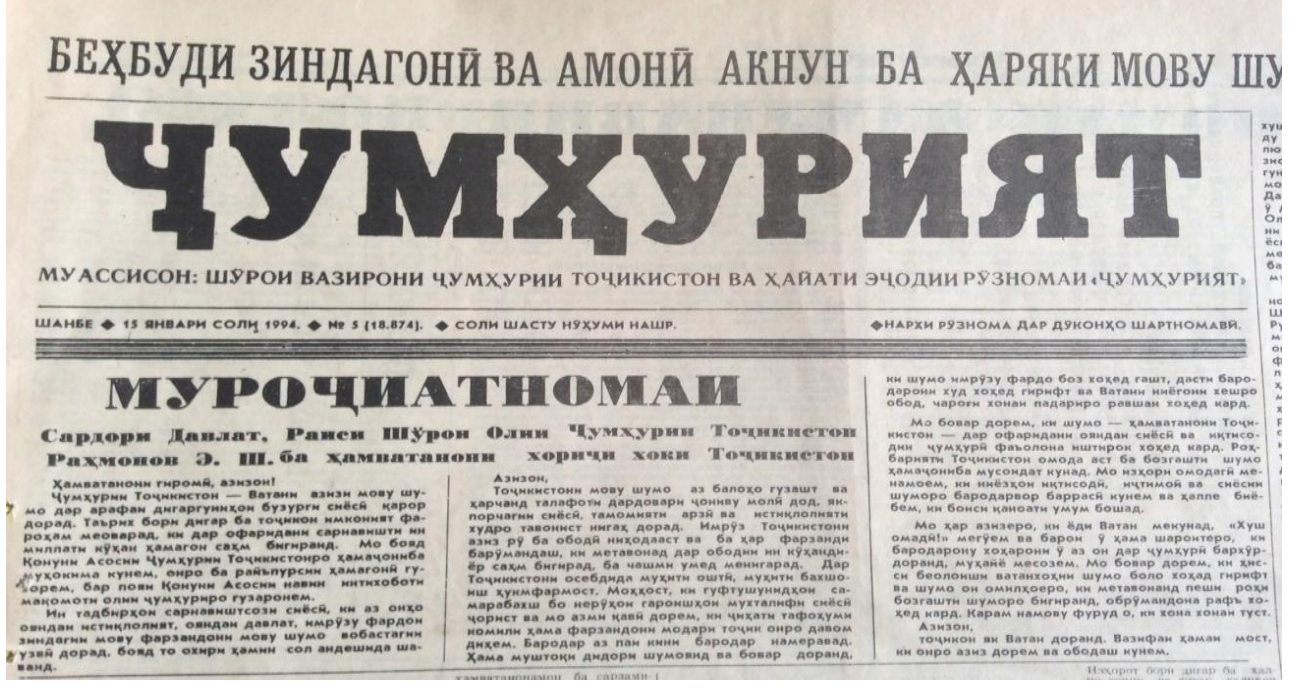

Figure 6. The Appeal of President E. Rahmonov

\section{Propagating Peace}

a) "Peace and national unity must be done in short term" ("Jumhuriyat" January 12, 1994, p.1). This article informs about E. Rahmonov's letter to UN Secretary General. In the letter the President asked the UN for help about return of refugees. It was the period, which Taliban was very active in Afghanistan. Therefore, the President cared about refugees.

b) "Unity and labor are basics of development" ("Jumhuriyat" March 2, 1994, p.1. see Figure 7 for the presidential call); 


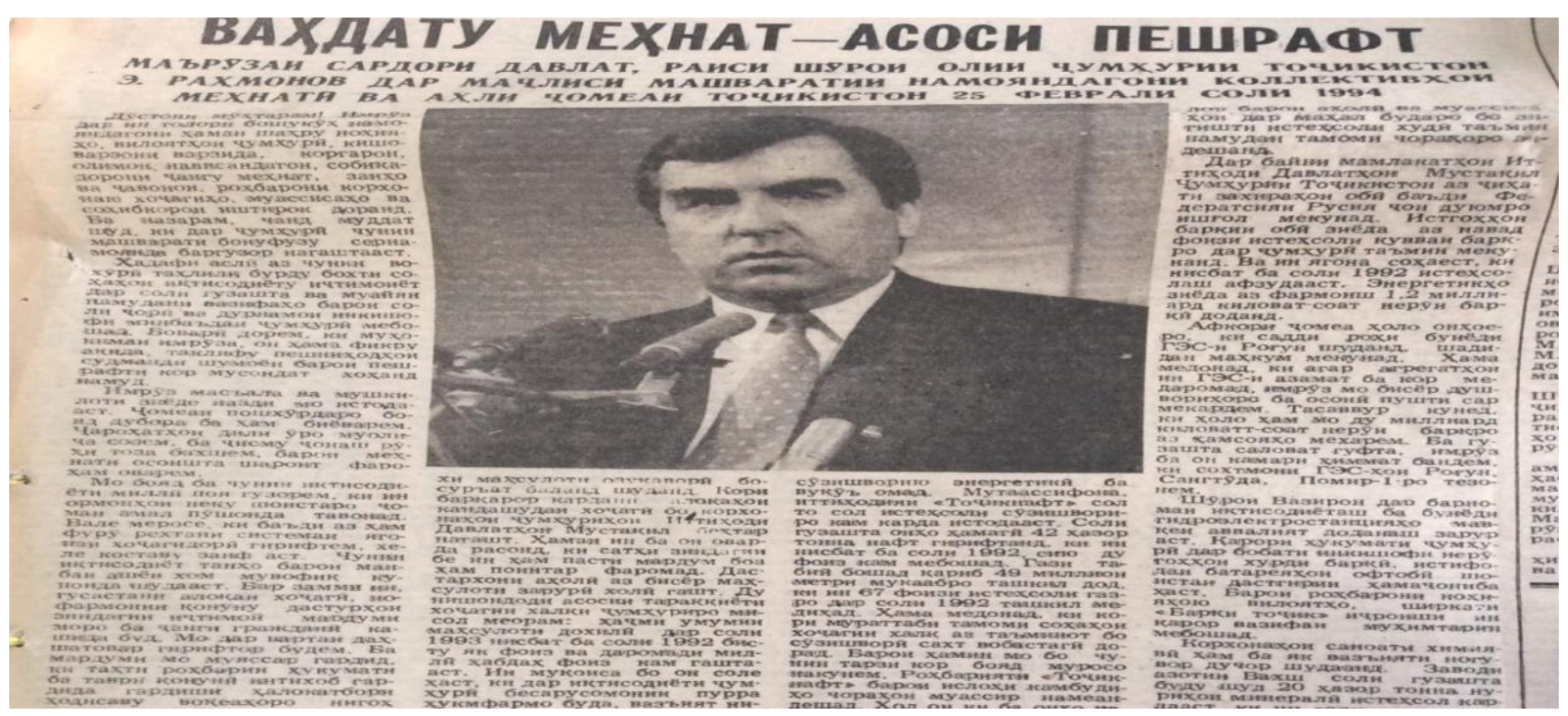

Figure 7. President Calling NGOs and Peoples to Peace

c) "The future of Tajikistan is in the unity of people and in hard working for future" ("Jumhuriyat" October 19, 1994, p. 1-2);

d) "The fruits of unity are sweet" ("Jumhuriyat" April 6, 1996, p.2);

e) "Reaching peace should be the purpose of all us" ("Sadoi Mardum" January 7, 1995, p.2);

f) "The biggest gift is forgiveness" ("Sadoi Mardum" July 12, 1995, p.3);

g) "In purpose to strengthen peace, unity and the freedom of Homeland" ("Sadoi Mardum" March 14, 1996, p.1);

h) "The only way is peace" ("Sadoi Mardum" July 10, 1996, p.1).

\section{Arms Delivery}

a) "Arms delivery is a right step in the way of calm" ("Sadoi Mardum" January 21, 1995, p.1);

b) "Arms delivery is the calm of the country" ("Sadoi Mardum" March 8, 1995, p.3);

c) "Arms delivery are continuing" ("Jumhuriyat" February 12, 1994, p.4).

\section{Peace Negotiations}

a) "Peace negotiations are started" ("Jumhuriyat" April 9, 1994, p.1);

b) "Today started second round of peace talks in Tehran. The wise thought will win?" ("Jumhuriyat" June 18, 1994, p.1);

c) "E. Rahmonov: We are satisfied with Tehran's peace talks results" ("Jumhuriyat" September 21, 1994, p.1);

d) "Ashgabat talks are promising" ("Sadoi Mardum" July 10, 1996, p.1);

e) "E. Rahmonov: We will reach our purpose (peace talks in Kyrgyzstan)" ("Sadoi Mardum” May 21, 1997, p.1).

\section{Peace Agreement}

a) "We will not turn back from peace way”(“Jumhuriyat” June 7, 1997, p.1); 
b) "E. Rahmonov: The purpose of all us is peace and calm in Tajikistan" ("Jumhuriyat" June 25, 1997, p.1);

c) "The peace of the Nation is the dream of all us" (Jumhuriyat June 28, 1997, p.1);

d) "In Tajikistan was signed NPA" ("Jumhuriyat" June 28, 1997, p.1. see Figure 8);

e) e) "Gerd Merrem (UN representative): We can congratulate Tajik people with peace" ("Sadoi Mardum” June 4, 1997, p.1).

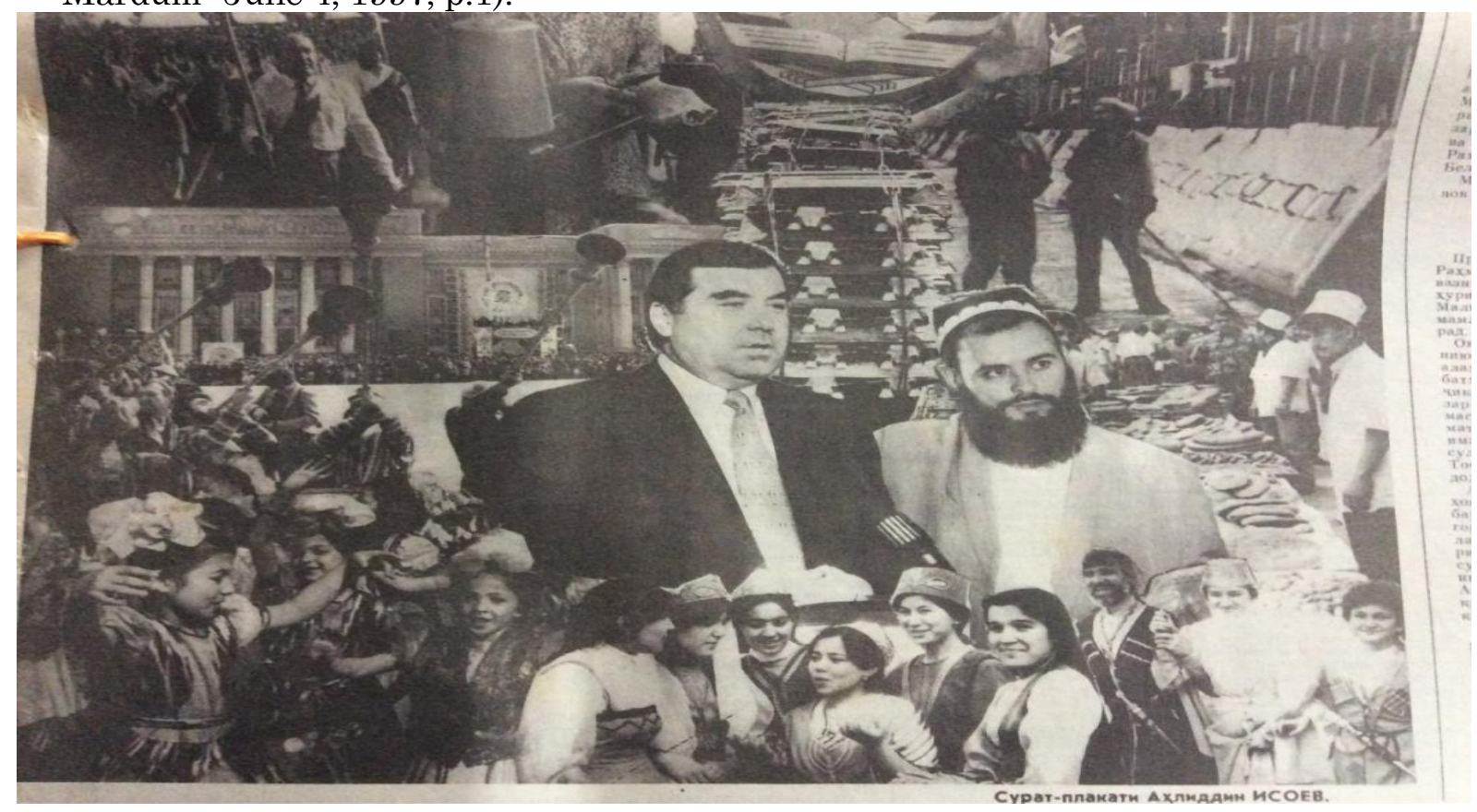

Figure 8. All People Celebrating Signing NPA

As we can see in the figure, people are happy that peace is reached. They are glad that they saw the day, which they have waited for five years. Another important detail in the photograph is that the leaders of the two conflicting sides are together. Thus "Jumhuriyat" newspaper used this photograph to give confidence to people.

\section{"Khoki Vatan (Homeland)" Radio Program}

As it was mentioned before, a lot of people become refugees during the civil war of Tajikistan. Most of the refugees migrated to Afghanistan. For this reason, returning of refugees was one of the most important issues in the peace negotiations period. Tajikistan government has also showed interest in this issue; therefore, the pro-government media were very active in this regard. One of the most effective programs which encouraged refugees to return to the country was "Khoki Vatan" radio program which was launched in 1993 by the "Radio of Tajikistan". The purpose of the program was to make refugees return home and to support the government's peace policy. The first broadcast was made under the name of "Homeland is better than the throne of Solomon". In this broadcast President E. Rahmonov said: "Dear citizens, I will not promise mountains of gold. We will share a piece of bread with you. Your homeland will protect you. Your homes, your families and your relatives are waiting for you ... Return to the country my dear citizens...!" In the third program, the name of the program changed to "Khoki Vatan (Homeland)."

Generally speaking, letters of refugees, letters of people who lost their relatives and peace promoting conversations were broadcasted in this program. In total, the program was broadcasted 800 times from 1993 to 1996. About 60,000 people sent letters from Tajikistan and 50,000 people sent letters from Afghanistan to their relatives and found their relatives (Hocazod, 
2014). Hence, the radio program "Khoki Vatan" became a tool of communication for those who lost their relatives during the civil war.

\section{Opposition Press in the Process of Reaching Peace}

As in any peace agreement, both conflicting sides were agreed for making peace in Tajikistan. Therefore, both side's media published peaceful views during the peace talks period in 1994-1997.

The opposition side published "Sadoi Mujohid (Voice of Mujahed)" brochure. This brochure spread among refugees in Afghanistan and in regions that were under the control of the opposition. According to Sulton Hamad, UTO used "Sadoi Mujohid" brochure for propagating peace between their supporters and it played a very influential role in reaching peace (Hamad, 2013. see Figure 9).

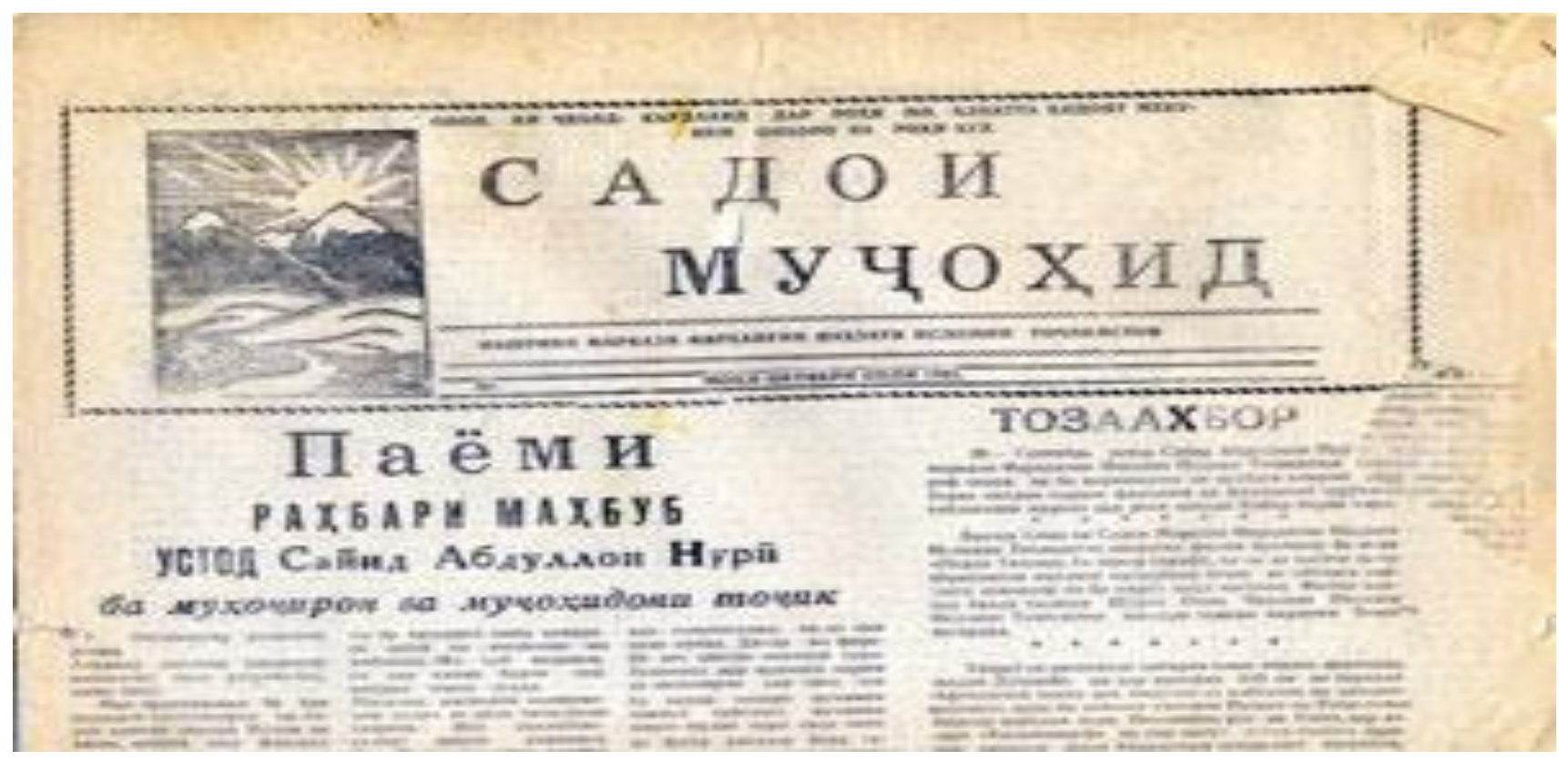

Figure 9. The "Sadoi Mujohid" Brochure

In the case of the peace propaganda from the UTO side, "Charoghi Ruz (private)" newspaper and foreign media such as the Radio BBC, the Radio Ozodi (RFE/RL), and the Radio Khuroson were also useful.

\section{CONCLUSION}

As the studies which were completed in several countries showed that the media generally played a negative role in civil war situations. However, during the civil war in Tajikistan, the role of media changed by the periods. The role of the media during the Tajikistan civil war was similar to the role of the media in the Northern Ireland conflict. In both cases, media (especially press) were helpful in reaching peace. It should also be stated that Tajikistan was not open to any media by international organization to promote peace. Because the local media were very active, it was not necessary to establish other peace promoting tools.

Before the conflict, the media caused increasing tension in the society. Political change and perestroika policy gave too much freedom to the media. This situation affected the actions of the 
media. During the conflict, the media which supported one side or another, acted to blame each other. On the other hand, when the peace negotiations started, media contributed to peace efforts. In general, during the civil war in Tajikistan, the media followed the general political situation, particularly the media that supported the conflicting sides. For example, when peace talks started, the media tried to disseminate this view in society. Furthermore, the media published or broadcasted the views of the sides during the meetings as well as the results of the meetings.

The role of the pro-government media should be particularly emphasized in this regard. As the present study showed in the case of peace promotion, the pro-government media were very active. Especially the position of the pro-government media has become clear after the start of the peace negotiations. In this sense, publications by "Jumhuriyat" and "Sadoi Mardum" should be mentioned. In addition, the government broadcasted the radio program "Khoki Vatan (Homeland)" in the Radio Tajikistan. This radio program was very extremely contributive and influential. Through these channels, the government shared its political views about negotiations.

In the case of peace propagation, the pro-opposition media (press) operated for the interest of peace too. Unfortunately, there is general information (not details) about the publications of the opposition media on the peace issue. However, as the case of signing the peace agreement showed clearly, both sides wanted and promoted peace.

In addition to the media, there were other actors that helped reaching peace. The important point in this case was realization of peace talks. This process has continued for about three years. A total of 9 rounds of official meetings along with 7 high level meetings and consultative meetings took place in the period of 1994-1997 toward the purpose of making peace. These meetings were organized successfully and were highly productive. Especially in the high level meetings the leaders solved a lot of problems which caused the civil war in Tajikistan. Therefore, organizing several rounds of meetings in different stages proved that both sides wanted peace and tried to reach it. Organizing various commissions proved this opinion too. Commission members from both sides worked together and it helped the sides understand each others. It is clear that the Tajikistan peace talks process was long, difficult, systematic, and eventually successful.

The civil war in Tajikistan affected country negatively from every side but Tajik people learned a few lessons from this war. Here are some of these lessons: (a) foreign countries never help a country in trouble without considering their own interests; (b) it is the ordinary people that suffer most in a civil war; (c) all civil wars end with some kind of results so the sooner the peace talks start the sooner the peace will be accomplished and suffering will be decreased; (d) the most important lesson from civil war was the lesson of reconciliation. This lesson is not just for the people of Tajikistan only, it can be a very helpful and important lesson for every society that experiences a civil conflict. According to the report of the UN's Office in Tajikistan, peace in Tajikistan is considered one of the five successful jobs of the UN regarding peace (Yusufjonova, 2005). According to Kofi Annan (Seventh UN Secretary General who served in 1997-2006), Tajik people gave the best sample of the reconciliation experience to other countries (Rahmon, 2011, p.3). 


\section{Recommendations}

1. The Tajik civil war showed that small differences in a society may appear too big during the civil war and people can use weapons against each other for simple reasons. In such situations the media should encourage common points of the conflicting sides.

2. No civil war has occurred without intervention of foreign countries but foreign countries have always followed their own interests. Therefore, conflicting sides should understand this point and they must find solutions by themselves and should not expect it from outside.

3. All conflicting sides and their supporters should want peace in order to start peace talks. Some interests can be a barrier to beginning of peace talks. In such situations, other countries and international organizations, which have not any interests from the conflict zone, should apply pressure on conflicting sides and their supporters.

4. There must be a common problem that conflicting sides should solve it. This common problem will help the sides to sit around the peace table. For example, the common problem in Tajikistan civil war has been the issue of refugees and power. When negotiations started, the conflicting sides at first tried to solve the issue of refugees. Therefore, in every conflict, the common problem of both sides need to be identified if applicable.

5. During the peace talks the conflicting sides should build trust and believe each other. Thus, they both must respect points that were agreed on. Otherwise, negotiations won't produce results.

6. In certain war zones, there may be some armed groups that act independently from the negotiating sides for peace. In this case, the sides that want reconciliation, must define their territories and positions clearly.

7. Both sides have to give up some of their goals. In other words, peace can only happen on common interests. For example, in Tajikistan, power sharing (70\% government, 30\% UTO) has made peace.

8. When possible or feasible, high level persons should participate in peace talks, not their representatives. This approach may produce expected results faster.

9. The reasons of the war must be explored in detail by the media and should be explained to the general public based on the versatile perspectives. It will help the parties understand each other and empathize on a certain scale.

10. There should be free, independent and reliable media establishments in conflict zones. International organizations and non-governmental organizations should support such alternative media without prioritizing the interests of other countries.

11. Faculties of communication should provide better training and learning opportunities on issues related to peace communication because their graduates will serve as media professionals in the future reporting serious conflicts and civil wars. 
12. Further research should be conducted on peace communication and conflict resolution efforts in other parts of the world experiencing civil wars. An accumulation of knowledge in this area may prevent or help resolving future conflicts.

13. New studies should investigate effective communication management strategies employed in multi-faceted civil wars together or alone by government institutions, opposition forces, media establishments, non-governmental organizations, neighboring countries, mediating actors, and international organizations.

\section{REFERENCES}

Abdulloev, I. (2013). UN and conflict between Tajiks: The peaceful role of UN in dialog between Tajiks. Nomai Donishgoh, 1, 100-109

Archick, K. (2015). Northern Ireland: The peace process. Congressional Research Service. p.23 . Retrieved October 23, 2017 fom file:///C:/Users/User/Downloads/3657.pdf

Batware, B. (15.01.2012). Ruandan ethnic conflicts: A historical look at root causes (Unpublished master's thesis). Peace and Conflicts Studies, European Peace University, Austria.

BBC. (14 May 2013). Hoci Akbar Turaconzoda. Retrieved March 24, 2017 from https://www.youtube.com/watch?v=yynzmNUcRII.

Bobokhonov, R.S. (2011). Civil war in Tajikistan (1992-1997 years): Causes, process, results and lessons. Social Science and Modernity, 4, 74-83

Buşkov, V.I., Mikulskiy, D.V. (1996). The anatomy of civil war in Tajikistan (Ethno-political process and political struggles, 1992-1995). Moscow: Russian-based Research Foundation. Retrieved January 20, 2017 from http://www.cac.org/datarus/st_08_bush. shtml.

Faroughi, P. (2002). Tajikistan: Nationalism, ethnicity, conflict, and socio-economic disparities - Sources and solutions. Journal of Muslim Minority Affairs, 22(1), 39-61

Hamad, S. (2013). How "Sadoi Mujohid (The voice of mujahid)" become the messenger of peace. Ruzgor. Retrieved April 5, 2017 from http://ruzgor.tj/sulh-oshti-vahdat/9471-chi-tavr-sadoi-mujohid-qosidisulh-shud-3302.html.

Hocazod, S. (2014). Barış ve birlik elçisi. Jumhuriyat. No: 70, S.3. Dushanbe.

Imomov, A., Sanders, G., Çufrin, G. (2014). The Inter-Tajiks dialogue within the framework of Dartmouth conference. Retrieved June 21, 2017 from http://www.cac.org/datarus/st_03_imomov.shtml.

Hoffmann, J. (2013). Conceptualizing communication for peace. UPEACE open knowledge network occasional papers. San Jose, Costa Rica: University of Peace.

Kabanda, M. (2007). Kanguare: The triumph of propaganda redefined. In A. Thompson (Ed.), The media and the Rwanda genocide (pp. 62-72). London: Pluto.

Kimani, M. (2007). RTLM: The medium that became a tool for mass murder (Statement by Kofi Annan). In A. Thompson (Ed.), The media and the Rwanda genocide (pp.110-124). London: Pluto Press.

$\mathrm{Li}, \mathrm{D}$. (2007). Echoes of violence: Considerations on radio and genocide in Ruanda. In A Thompson (Ed.), The media and the Rwanda genocide (pp. 90-109). London: Pluto.

Murodov, S. (2015). The role of mediator institutions in social and political conflicts. Dushanbe. Tajikistan: State University of Pedagogy.

Panfilov, O. (2003). Tajikistan: Journalists during the civil war (1992-1997). Prava Cheloveka, Moscow.

Rahmon, E. (2011). Independence of Tajikistan and revival of nation. Irfon, p.576

Saunders, H.H. (2001). The Inter-Tajik dialogue (A public peace process: Sustained dialogue to transform racial and ethnic conflicts. New York: Palgrave.

Schmitz, A. (2015). Islam in Tajikistan: Actors, discourses, conflicts. Berlin: Stiftung Wissenschaft und Politik German Institute for International and Security Affairs.

Sharafieva, O.K. (2013). (Ed.). Negotiations between Tajiks as a sample for resolving civil wars (pp.84-91). State University of Tomsk (Publication No 367).

Wolsfed, G. (2004). Media and the path to peace. New York: Cambridge University Press. 
Yusufjonova, Z. (2005). Peacebuilding in Tajikistan. Joan B. Kroc Institute for International Peace Studies at the University of Notre Dame. Retrieved July 2, 2017 from http://www.beyond intractability.org/casestudy/yusufjonova-peacebuilding.

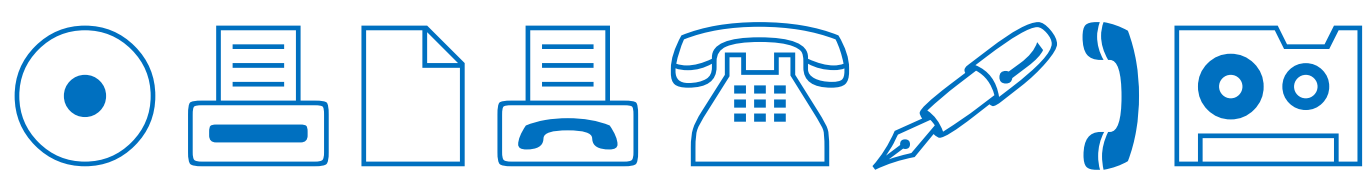

